\title{
The Communication Strategy of the Indonesian Solidarity Party (PSI) in the 2019 General Election Political Campaign in New Zealand
}

\section{Sylvia Roennfeld}

Institute of Communication and Business LSPR Jakarta, Indonesia sylvia.ar@lspr.edu

\section{Yunita Permatasari}

Institute of Communication and Business LSPR Jakarta, Indonesia yunita.ps@lspr.edu

\section{Volodymyr Kyrychenko}

Higher School of Economics, Russia

Volodymyrkyry@gmail.com

Submitted: 25 January 2021; Revised: 7 April 2021; Accepted: 20 April 2021

\begin{abstract}
Abstrak
Penelitian ini menganalisis strategi kampanye politik Partai Solidaritas Indonesia (PSI) sebagai pendatang baru di pemilihan umum 2019 dalam meraih suara pemilih luar negeri, kasus yang dipilih berfokus pada kemenangan PSI di Selandia Baru pada perhelatan pemillhan umum 2019. Pertanyaan utama di dalam tulisan ini adalah bagaimana strategi kampanye politik PSI di Selandia Baru sehingga bisa memenangkan suara pemilih di sana pada pemilu 2019? Pertanyaan ini akan dijawab menggunakan teori strategi komunikasi yang menekankan pada kriteria visi dan misi, program dan kegiatan, tujuan dan hasil, seleksi audiens, perumusan pesan, identifikasi pembawa pesan, dan mekanisme komunikasi/media. Setidaknya dari upaya tersebut akan diperoleh gambaran mengenai strategi komunikasi politik yang direncanakan dan diimplementasikan oleh PSI, serta pengolahan pesan dan medium komunikasi yang digunakan untuk meraih suara pemilih luar negeri di Selandia Baru sehingga dapat membawa kemenangan PSI di sana. Studi ini penting baik dalam ranah akademis maupun praktis. Pada ranah akademis dapat memperkaya studi komunikasi yang tertarik pada isu-isu terkait komunikasi politik dan kampanye politik dari partai baru di dalam denyut nadi alam demokrasi Indonesia. Sedangkan pada ranah praktis, dapat menjadi rekomendasi strategi bagi partai-partai yang nantinya akan berkontestasi pada pemilu 2024 di dalam pesta demokrasi di Indonesia berikutnya.

Kata Kunci: Partai Solidaritas Indonesia, pemilu 2019, Selandia Baru, strategi komunikasi, komunikasi politik.
\end{abstract}

\begin{abstract}
This research analyzed the PSI political campaign strategy in gaining votes from overseas voters by taking the case of PSI's victory in the 2019 general election in New Zealand. The main question in this paper is how the PSI political campaign strategy in New Zealand could win votes in the 2019 general election? To tackle this question, we used a communication strategy theory that emphasizes the vision and mission criteria, programs and activities, objectives and results, audience selection, message formulation, identification of message carriers, and communication/media mechanisms. This research utilized a qualitative method with two data collection techniques-primary and secondary. This research aims to examine the political campaign strategy of PSI in the 2019 general election in gaining overseas voters, specifically focusing on the winning of PSI in New Zealand. This study also aims to draw the campaign strategy, message processing and communication media used to attract overseas voters to gain victory.

Keywords: Indonesian Solidarity Party, 2019 general election, New Zealand, communication strategy, political communication.
\end{abstract}

\section{INTRODUCTION}

Since the 1998 reformation, democratization in Indonesia finally applies a democratic political system by conducting general elections for the president and legislative members to vote for the representatives and the leader of the country. This policy was initiated during the era of President Abdurrahman Wahid. It was then 
approved by President Megawati in Law No. 23 of 2003 concerning the General Election of the President and Vice President (Permana, 2019). This trajectory strengthens the importance of the political campaign in a country with almost 270 million populations. Furthermore, the Indonesian political campaign is shifting to be more American, turning its style from institutional to more personal (of the candidates), also known as personalization of politics where electoral votes of the voters depend on their proximity and relationship with the political candidates (Swanson \& Macini,1996: 14-17). For example, many observers believed that President Susilo Bambang Yudhoyono's victory in 2004 was due to his personality image as a presidential candidate acceptable to the people (Ardaneswari, 2020). Therefore, political campaign strategy becomes an essential concept in the democratic political constellation in Indonesia. The failure of formulating the strategy can cause a political party failure in joining the power spectrum in Indonesia.

A general election is a democratic platform where people reflect their nation's sovereignty. In a democratic country, the general election also becomes the moment of truth where the people voice out their aspirations, and they get to decide the direction of the country. These voices are to be accommodated in the political parties participating in the election to represent the people in the House of Representatives (DPR). According to the Constitution No.10 of 2008 about General Elections for the Representative of People Council, Regional Representative Council, and Regional Representative of People Council, general elections are defined as the facility where people can directly cast their votes in the base of directness, generality, freedom, confidentiality, transparency and fairness as regulated by the 1945 State Constitution of the Republic of Indonesia.

At the level of theorizing political system and democracy, an understanding of democracy is manifested in the meaning of "the procedure to form a broad government", which is what general elections mean. Hence, the word is an essential embodiment of "procedural democracy". Samuel P. Huntington in "The Third Wave of Democracy" mentioned that "the main procedure in democracy is the direct election of the leaders competitively by the (to be) ruled-people (Huntington, 1993). Moreover, general election is aligned with the democracy spirit, known as substantial democracy, meaning that the government runs from, by and for the people. The people hold the highest sovereignty in the heart of national politics, where the aspirations are the manifestations of God's voice (Vox Populi Vox Dei). Thus, general election is an institution and a procedure in political practice to shape a representative government, which according to Robert Dahl $^{1}$, is the ideal and maximum illustration of modern people government.

Political parties must prepare the rightest communication strategy to achieve their political objectives and win the contest to collect the most votes to be the legislative representatives of the people. Political communication benefits a political party. One of the communication elements is to present self-identity; thus, proper communication will enable the right message and right identity of the political party to the public. This political party identity then creates the people's sympathy and leads to winnings (Liliweri, 2010).

The public perception toward a company, organization, political party or individual is affected by how they understand the entity. The correct understanding of the organization will result in the proper support and decent, sustainable and favorable relationship (Carrol \& McCombs, 2003).

The correct understanding of a reputation will then result in public perception and support based on the excellent reputation in their mind. Reputation, therefore, is achieved through well-planned, systematic, measurable and sustainable planning. This understanding also applies to political parties as entities in a dynamic political life. The ability to build a broad public understanding of the existence of a party is essential.

Public relations in an organization have the task of understanding the public through structured communication (Cutlip et al., 2000). Furthermore, Bernays (1952) suggested three crucial elements in public relations: informing, influencing, and integrating with 
the public. This argument highlights the importance of the public relations role in providing the right information to the public to gain an excellent organizational reputation and maintain a good relationship between the organization and its people.

Political parties with the same orientation, values, and ideals aim to gain political power and seize political positions by constitutional means to implement their policies (Budiarjo, 2002). As one of the pillars of democracy, political parties are organizations requiring support from the public or their constituents. The survey conducted confirmed that the public gave political parties support or votes based on their reputation in society (Kemenkumham, 2020).

Public support for political parties is not only based on their greatness, but society will also assess their performance and reputation. In Indonesia, the general election system for the legislature is carried out using an open proportional system. Every citizen can directly elect a party or candidate for legislative members (Hukum Online, 2020). Elected candidates are not determined based on their serial number in a political party but by the most votes cast by the voters. The increased critical public followed by the easy access to social media and freedom of opinion has made existing political parties more observant and careful in maintaining their reputation. Public perception matters for them to gain votes in the elections.

Public apathy toward Indonesian politics is caused by various reasons, such as rampant power struggles, unclear political rhetoric, debates on social issues for political interests, the emergence of identity politics to gain power, and various corruption cases involving party elements. These are the issues that require political parties as organizations to always be aware and practice transparency, consistency, and commitment in running their constituent tasks. Learning from what Democratic Party had experienced when its reputation was degraded due to many issues and problems within its public image and corruption cases involving its people. Tempo.com recorded ten corruption cases done by Democratic Party involving the leaders and even the former President Susilo Bambang Yudhoyono and have caused them to lose their electability. After winning the 2009 legislative election with $20.85 \%$ of the votes, their electability dropped to $10.19 \%$ in 2014 and continued to shrink to around 8\% in 2020 (Mata Mata Politik, 2019).

The 2019 general election held on April 17, 2019, was the first election in which the legislative and presidential elections were held simultaneously. The legislative election aimed to elect 575 members of the House of Representatives (DPR), 136 members of the Regional Representative Council (DPD), and members of Regional People's Representative Assembly (DPRD Provincial and City/Town levels) in Indonesia from 2019 to 2024. The number of parties registering to participate in the 2019 elections was 27 parties. Unfortunately, in the end, only 14 parties met the administrative and factual verification requirements nationally. Four of them are new parties participating in the 2019 elections, namely the United Indonesia Party (Perindo), the Berkarya Party, the Indonesian Change Movement Party (Garuda), and the Indonesian Solidarity Party (PSI).

Verification requirement includes the participation of the main members of the party in the center level, where women's representation reaches $30 \%$, and office location is within the Central Representative Council. Following that, at the provincial level, additional requirements are such as: fulfilling the membership of $75 \%$ City/Town in 34 provinces in Indonesia, and the last requirement is to have at least $50 \%$ offices in districts in at least $75 \%$ of cities or towns in 34 provinces. According to the General Elections Commission (KPU), the total number of registered official voters in the 2019 elections based on the results of the DPThp 3 recapitulation, December 15, 2018, amounted to $192,828,520$ voters. This number consisted of 190,770,329 voters in Indonesia and $2,058,191$ voters abroad. To serve overseas voting, the KPU formed 130 Overseas Election Committees (PPLN) to serve Indonesian citizens in 98 countries. (CNN Indonesia, 2019)

There is an interesting phenomenon during the last 2019 elections, where big parties such as PDI Perjuangan and GOLKAR experienced a decrease in winning votes abroad. However, as one of the new parties participating in the election, PSI reaped extraordinary results. In several countries such as the United States, Sweden, 
Latvia and New Zealand, this party won the most votes. One interesting case is its victory in New Zealand, which took place in two cities, Wellington and Auckland. The election was held simultaneously on April 13, 2019. According to a release given by the Indonesian Embassy in Wellington, from the vote count results, Jokowi-Kiai Maruf Amin was far ahead with the acquisition of $85 \%$ (2,085 votes). Meanwhile, Prabowo-Sandiaga Uno received 13\% (312 votes) and 2\% (44 votes) invalid ballots. Meanwhile, for the legislative election for DPR RI members, the largest vote was taken by PSI (37.82\%), followed by PDI-P (37.38\%), PKS (7.30\%), Gerindra (3.4\%), Nasdem (2.99\%), the Golkar Party (2.86\%) and PKB (2.59\%). Other parties such as PAN, Democrat, Perindo, PPP, Hanura, PBB, Garuda, Berkarya and PKPI received votes below 2\% (Kementerian Luar Negeri, 2019).

Referring to the Indonesian Embassy data in Wellington, the achievements obtained by PSI are very significant and interesting because it won the most votes, despite being a new party and its first time to participate in the elections. Even though in the end, with the existing votes, PSI did not meet the threshold requirements to sit in the Central People's Representative Council, however, from the total number of votes, including voting contributions from foreign voters, it still had the opportunity to sit as the people's representatives in DPRD Jakarta because the votes coming from overseas were counted toward the votes of the DKI Jakarta regional voters.

As reported by the website of PSI, the new party participating in the election was founded based on idealism and the awareness that politics is a noble task to create welfare for everyone. The party led by Grace Natalie as the General Chairwoman, Raja Juli Antonie as the Secretary-General, Isyana Bagus Oka as the Chairwoman of the Central Board (DPP/Dewan Pimpinan Pusat) and several other young people, PSI offers a face of a less rigid and more popular political party. As stated by its General Chairwoman, Grace Natalie, "PSI is here with everything new: new ideas, new initiatives, new ways, new people and new machines". Referring to ideas, ideals, and concepts, PSI wants to target potential young constituents or voters as the old parties have not touched them. The Ministry of Home Affairs (Kemendagri) recorded 5,035,887 new voters in the 2019 elections. These data are included in the List of Potential Election Voters (DP4).

The victory phenomenon of the PSI in several countries is an interesting matter to be studied further, especially in terms of the Public Relations strategy in political communication, which resulted in significant support from overseas voters. Compared with established parties, PSI does not yet have adequate infrastructure to gain support from overseas voters. It does not even have a representative party office overseas. It is quite interesting, especially compared to other political parties such as PDI Perjuangan, which has representatives in the United States, Malaysia, Saudi Arabia, Brunei, Germany, Hong Kong, the Netherlands, Australia, and Belgium. Even in Malaysia, there are seven representatives of political parties from Indonesia: the National Awakening Party (PKB), PKS, Golkar Party (PG), the Democratic Party (PD), and the National Mandate Party (PAN) (Surabaya Tribbun news, 2009).

Therefore, this research aims to examine the political campaign strategy of PSI in the 2019 general election in gaining overseas voters, specifically focusing on the winning of PSI in New Zealand. This study also aims to draw the campaign strategy, message processing and communication media to attract overseas voters to gain the victory. Both academically and practically, this study aims to contribute to communication and political communication, as well as old and new parties in running their existence and fighting for the welfare of the people in the country. This study also aims to reference those who want to run for candidacy in the 2024 general election based on the analysis.

\section{LITERATURE REVIEW \\ Political Communication Strategy and Political Campaign}

Based on Dan Nimmo's (1989) argument, political communication is a communication activity involved in politics with the basis of actual and potential consequences to rule people's attitude in conflict 
to rule people's attitude in conflict circumstances. On the other hand, Miriam Budiardjo (1982) suggested that political communication is based on one of the political party functions to broadcast their political opinions and ideas to create interest aggregation and articulation formed into a political policy. A political communication strategy must be planned accordingly to convey political messages to the public in political communication.

Politics, both vertically and horizontally, has dynamic conditions in which every act of communication aimed at articulating political interests must be formulated effectively and appropriately. Hence, effective communication actions are largely determined by the communication strategy. On the other hand, no good communication strategy will likely affect the communication process (especially mass media communication) and have a negative effect. Meanwhile, the communication process can be examined using communication models. In the process of ongoing or finished communication activities, a communication model can be used to assess the success of the communication process, especially its effect.

Onong Uchjana Effendi, in a book entitled "Dimensions of Communication" stated that "communication strategy is a combination of communication planning and management to achieve a goal. The communication strategy must be able to show how the plan is technically carried out, in the sense that the approach can be different at any time depending on the situation and conditions" (Effendy, 2003). The approach to political communication is fundamental, especially when it is intended for election contestation conditions.

General election activities cannot be separated from campaign activities. Based on the elaboration of Article 1 paragraph 26 of the Constitution No 10 of 2008 concerning the General Election of DPR, DPD, DPRD, the definition of the campaign is the activity of election participants to convince voters by offering the vision, mission and programs of election participants. In short, a campaign can be interpreted as an activity containing a purpose to something. Similarly, Cangara explained that a campaign is a communication activity aimed at influencing people so that they have the ideas, attitude and behavior according to the wishes or desires of the spreader or information provider (Cangara, 2011).

Additionally, Imawan (in Cangara, 2012) argued that a campaign is a persuasive effort to summon people who still disagree and are unsure about the suggested ideas to believe and hold them. Campaign definition, according to Kotler and Roberto (in Cangara, 2012), is "an organized effort conducted by one group (the change agent), which intends to persuade others (the target adopters), to accept, modify, or abandon specific ideas, attitudes, practices and behavior.

Therefore, a political campaign as an activity that aims publicity and convinces the public in the general election is significantly related to political marketing. Based on the concept, this research argues that political campaign emphasizes the effort to articulate the message intensively in a particular time to gain influence from the political public. The sole hope of the campaign is to create the willingness of the people to vote for the candidates of the legislative who carry out the campaign.

\section{RESEARCH METHOD}

Based on the two concepts elaborated above, which are political communication and political campaign, this research analyses the communication strategy of PSI in winning the general election in New Zealand. This research uses a constructivism paradigm, with a qualitative approach and case studies. The use of qualitative methods in general is to describe and interpret a process that exists in human social life. One form of qualitative research methodology is a case study.

A case study is a type of qualitative research in which the researcher conducts research on one or many cases at the same time. The case study research generally uses various kinds of data and information, case descriptions, or cases related to the research theme. In social science research, case studies have the nature of explanatory, exploratory and descriptive research. The main function of case studies is to explain, find and describe a case, either single or multiple cases (Creswell \& Creswell, 2017). In this study, the researchers used a qualitative method and a case study using a descriptive approach. 
Data sources used in this research are in two forms, primary and secondary data. Primary data were obtained through interviews, while secondary data were collected from books, reports, and credible open sources to deepen the analysis. We conducted an in-depth interview with the Chairwoman of PSI Central Board, the secretary of the Overseas Election Committee (PPLN) in the Indonesian Embassy at Wellington, and Indonesian voters in New Zealand working at the Indonesian Embassy. This research is expected to provide input on how PSI's political communication strategy in gaining votes from foreign voters and the political public relations strategy used as a new party participating in the election to gain sympathy and voter support.

\section{RESULT AND ANALYSIS INDONESIAN SOLIDARITY PARTY AND THE 2019 GENERAL ELECTION}

In the 2019 general election, 14 parties competed. Four new parties joined and aimed for votes in the 2019 election contest from all of the parties. One of them was PSI. This party, targetting young people, was founded after the 2014 presidential election (Partai Solidaritas Indonesia, 2019) by a news presenter Grace Natalie who also became the Chairwoman. At this time, the Central Leaders of this party consist of nine people: Grace Natalie, Raja Juli Antoni as Secretary-General, the Chairwomen of the DPP, namely Suci Mayang Sari, Isyana Bagoes Oka, Tsamara Amany, Sumardy Ma, Danik Eka Rahmaningtyas, Satia Chandra Wiguna, and Lila Zuhara. Isyana Bagoes Oka is known to be a former television presenter. Meanwhile, Tsamara is widely known as a young Twitter celebrity and activist.

However, according to the 2019 election results, PSI did not qualify for a seat in the People's Representative Council of the Republic of Indonesia (DPR-RI). The KPU recapitulation results were set on Tuesday, May 21, 2019, through the KPU Decree No. 987/PL.01.8-KPT /06/KPU/V/2019 concerning Determination of the General Election Results for the President and Vice President, Members of the Regional Representative Council, the Provincial Regional People's Representative Council, the Regency/City Regional People's Representative Council nationally in the 2019 general election. PSI won 12th place out of 17 political parties with a total vote of 2,650,361 million or $1.89 \%$ (Kompas, 2019). This result was humbly received by PSI leaders, although they did not pass the $4 \%$ parliamentary threshold. Secretary-General of PSI Raja Juli Antoni said that their vote acquisition was a significant asset for the party to prepare for the next election contest in 2024.

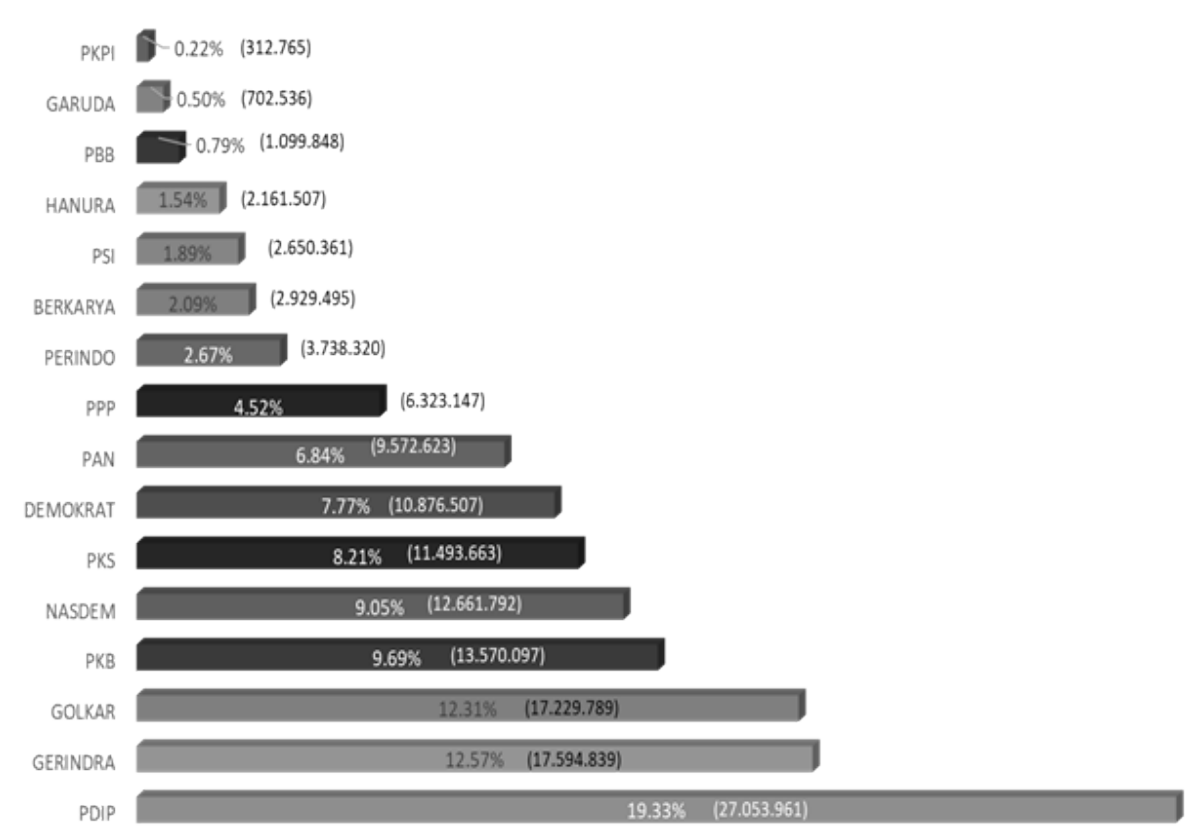

Figure.1 Legislative Election Recapitulation Results 2019 (Data adapted from Tagar, 2019) 
"Today, the quick count results are similar to the results released by the KPU and once again with pleasure, these are the results of our struggle, around 3 million PSI voters are the main capital for us to move on the next five years," (Kompas, 2019).

The large capital referred to by Raja Juli as the Secretary-General of PSI is the result of the 2019 election contestation, showing that PSI has been highly powerful in the elections held abroad. It excelled in developed cities, such as Sydney and Melbourne (Australia), Washington DC (United States), The Hague (Netherlands), and New Zealand. It was the top party with 4,912 votes or $39 \%$ of the total votes in Sydney, Australia. It sat in the highest position for the legislative elections, following under PSI in a row, PDI-P with 4,680 votes or $37 \%$, PKS with 1,240 votes or $10 \%$, NasDem with 409 votes or 3\%, and Gerindra with 350 votes or $3 \%$. Even more extraordinary, PSI has also won in New Zealand, for the legislative election for members of the Indonesian Parliament, the largest vote was taken by PSI (37.82\%), followed by PDI-P (37.38\%), PKS (7.30\%), Gerindra (3.4\%), Nasdem (2.99\%), Golkar (2.86\%) and PKB (2.59\%). Other parties such as PAN, Democrat, Perindo, PPP, Hanura, PBB, Garuda, Berkarya and PKPI received votes below 2\% (Kementerian Luar Negeri, 2019). This phenomenon shows that the identity of PSI as a political party is powerful in the competition for votes in the elections held abroad. Its strategy to achieve these results finds its importance to be studied in depth.

\section{COMMUNICATION PLANNING AND MANAGEMENT OF INDONESIAN SOLIDARITY PARTY IN NEW ZEALAND}

As mentioned previously in the theory section, effective communication acts can be largely determined by determining the communication strategy. On the other hand, if there is no good communication strategy, the communication process (especially mass media communication) might have a negative effect. Meanwhile, the communication process can be examined using communication models. In the process of ongoing or finished communication activities, to assess the success of the communication process, especially the effect of the communication process, a communication model is employed.

Meanwhile, in a communication strategy, understanding the combination of communication planning and management to achieve goals is crucial. To achieve the objectives, the communication strategy must be able to show how the "implementation is technically carried out, in the sense that the approach can be different from time to time depending on the situation and conditions" (Effendy, 2003). This view is in line with the explanation of the sources of this research from previous literature. Theoretically, the first thing that becomes a reference for formulating a political campaign strategy is the organizational goals. This goal setting then demands ways and communication techniques that play a role in supporting the achievement of goals more efficiently and effectively. The strategy must be adaptive to the situation, responsive to demands, and in line with the party's ideology. The recognition of voters' public interests is also an essential factor in creating reciprocal communication needed for a modern organization (Susanto, interview, 2020). This paper agrees with the views previously presented. Therefore, understanding PSI's political campaign strategy in foreign elections must rely on communication planning and management aspects.

This paper obtained essential data based on interviews with the speaker of the PSI DPP Chairwoman. The main strength in PSI's political campaigns abroad is the programs and messages conveyed consistently with relevant and actual issues to the lives of young people abroad with modern and educated thinking. PSI is famous for its two main issues or messages: corruption and intolerance; other programs only support them. In Indonesia, based on research, people vote based on political issues; only $11 \%-14 \%$ have a political ideology, while the rest are swing voters who are big enough to determine the election victory. Tactically and based on evaluation of the steps taken, it is also essential to analyze the data using the political communication approach and political campaigns. These data have also been triangulated as valid with information from voters in the 
2019 elections in New Zealand. The source of this research stated that,

"The Indonesian Solidarity Party is quite interesting in offering something new to us young people, especially since I see that most of its contents are young people who have a concern for the progress of our nation and country. I am quite impressed by the courage of PSI because even though it is a fairly new party, it has dared to raise quite sensitive issues and invite a lot of controversies, such as the issue of corruption and intolerance. I also see that PSI is quite active on social media, and helps us to understand its views on issues that matter to us" (Raharja, interview, 2020).

Raharja reviewed the phenomenon of overseas voters who have lived in New Zealand for two years as students and interns at the Indonesian Embassy. PSI's political campaign through social media, which consistently showed its identity as a political party that offered the novelty and actuality of educated and young people in the 2019 election contestation, has been well received by them and made Raharja chose PSI during the 2019 general election in New Zealand.

In planning and communication management for conducting political campaigns, PSI prioritized data generated from internal party research. These data reinforced its political campaign program, focusing on two parametric issues: corruption and intolerance. The formulation of a political campaign program supported by data combined with the consistency of the direction of the political views of the parties moving to become the supporting roots of democracy had made the political campaign program implemented had strong relevance. This view is contained in the information from the informant explaining the relationship between campaign program planning activities that focus on the synergy between internal data from research results and the consistency of political views.

"As I explained earlier, PSI always uses data from internal research in making steps and actions toward issues in society, especially on the two main issues that become PSI's focus, corruption and intolerance. Therefore, the formulation of messages on political communication is always carried out based on research and consistency of PSI's political views and philosophy, which is to make a political party as a political party following its actual functions in the pillars of democracy, not as a political party that only prioritizes its interests above the people's interests. Also, perhaps because Indonesian people who live abroad are used to seeing how political parties function well in the process of democracy in certain countries, so we think that is what makes all this relevant" (Sumardy, interview, 2020).

PSI's political campaign program planning to win the election in New Zealand was also supported by overseas party management infrastructure development. Thus, in the execution of its program, it also paid attention to the strength of the management that relied on its cadres abroad. Sumardy also alluded to this, and PSI did build infrastructure for party management abroad, such as in Singapore and Hong Kong, to help disseminate its content and make visits. With the existence of strong supporters and followers as the support capacity for political campaigns abroad, PSI could easily and effectively get the opportunity to campaign abroad through activities that invited important PSI figures to speak in several countries, such as in Australia, Hong Kong and several other countries (Sumardy, interview, 2020).

\section{FOUR ELEMENTS OF COMMUNICATION STRATEGY OF INDONESIAN SOLIDARITY PARTY IN NEW ZEALAND}

The communication strategy also has several quality criteria or standards. The strategy starts with: (1) Identifying the vision and mission. Vision is a long-term ideal that can be achieved through the communication process. The vision formulation usually consists of "a few words" containing the goals, hopes, and communication ideals. (2) Determining programs and activities. Programs and activities are a series of activities that must be done and the descriptions of the mission. (3) Determining goals and results. Every program or activity usually has a goal and the results to be obtained. Usually, the policymakers define the goals and results to be achieved. (4) Selection of the target audience. 
Communication planning determines audience categories as the target of communication. This paper presents an understanding of the quality of political communication possessed by the PSI political campaign in New Zealand based on those four elements.

\section{Identifying the vision and mission}

As a new political force in Indonesia, PSI was born from the awareness that politics is a noble task to create welfare for everyone. Thus, this party wants to bring politics back closer to the values of virtue so that politicians will, whose thoughts and actions are based on the greater interest of the Indonesian nation and people, is not just short-term political, personal interests (Partai Solidaritas Indonesia, 2019). Following the explanation of the Chairperson of the DPP of PSI, PSI, from the very beginning, has determined its main mission to place political parties as pillars of democracy. Hence, political parties must represent the aspirations of the people to voice them as political aspirations. This role is crucial for forming a better Indonesian society in the future.

\section{Determining programs and activities}

Therefore, this vision and mission became the basis for PSI to determine the focus of the issues to be communicated in its political campaigns abroad, including in New Zealand. In line with PSI's national political campaign program, its political campaign in New Zealand also focused on corruption and intolerance issues. Its commitment to build an anti-corruption image was also communicated symbolically through activities concerned with corruption issues, especially in power politics. One of the activities demonstrating this effort was the action in collaborating with Indonesia Corruption Watch (ICW) to conduct a workshop for all its legislative candidates at that time. Following the explanation of the Secretary-General of PSI, "We want to ensure that each member of the Provincial and Regency/City DPRD elected from PSI can understand the functions and duties of a council member. They also learn the ins and outs of corruption cases, and in turn, they can be free from corruption cases" (Partai Solidaritas Indonesia, 2019). The explanation from the PSI
Secretary-General is also in line with the information from the informant.

"Our program and message are delivered consistently with the relevant and related issues with modern, educated and open-minded young people overseas. PSI is known for two issues, corruption and intolerance; other programs are supporting them. In Indonesia, based on research done, people vote based on a political issue, only $11 \%-14 \%$ of them have a political ideology, while the rests are swing voters with big chance to win the elections (for PSI)" (Sumardy, interview, 2020).

In the political campaign, PSI intensively focused on two key messages for its voters: anti-corruption and anti-intolerance. Therefore, those two central issues have been the highlight in every political campaign of PSI.

Ideas relevant to eradicating corruption and maintaining tolerance in Indonesia have become a central theme in various PSI political campaign programs, especially in New Zealand. For example, in the context of intolerance, PSI strongly condemned the brutal shooting at two mosques in Christchurch, New Zealand. The Chairwoman of the PSI DPP, Tsamara Amany, at that time stated, "We, PSI, strongly condemn the barbaric acts of terror in New Zealand, especially the location of the incident was in a mosque". It did not stop there; sympathetically, PSI sent a wreath of condolences to the New Zealand Embassy in Indonesia.

PSI's move to condemn the event in New Zealand and send a wreath of condolences, of course, could not be interpreted as merely a sympathetic attitude or a form of party solidarity. However, this action was also an effort to build PSI's image as a very anti-intolerant party. The related issue about intolerance within Indonesian people was an easier issue to catch for overseas Indonesian people, especially in New Zealand that had just experienced the shooting incident. The majority of Indonesians living in New Zealand were young people studying or working. Thus, they were relatively more advanced in their thinking and promoted tolerance regarding individual rights. Ideas related to anti-intolerance are easier for Indonesia's younger generation to absorb. This opinion is in line with the 
informant of this research,

"In several countries, especially non-Asian countries such as Europe and New Zealand, according to our internal assumption, many Indonesians who are still relatively young and live there see the ideas that PSI is fighting for. Incidentally, there is also a high degree of tension regarding religious intolerance. PSI is the only party that openly fights for intolerance through speech or content. Hence, we also adjust the segment accordingly, and the programs offered are appropriate because none of the other parties dare to touch the issue. The 2019 elections had a very high political stigma, such as between Islam and anti-Islam. Thus, PSI was brave enough to be present in that situation so that the message conveyed was clear and different from other parties. Meanwhile, many young people abroad saw the ideas offered by PSI as interesting or relevant to their lives. It happened that PSI was the only party persistent in bringing up issues of inter-religious intolerance, corruption, etc. Based on the data, there was no single party giving serious attention” (Sumardy, interview, 2020).

\section{Determining goals and results}

As a goal, PSI wants to show its struggle to restore the role of political parties in an ideal way in the narrative of fighting against issues of corruption and intolerance. This research gathered primary data regarding the initial plan of PSI establishment as a political party. The initial mission of the PSI establishment is to place a political party as a trustworthy party and to conduct its role as a democracy pillar. The philosophy is that PSI is a party philosophically close to the people, consistent in getting people's assessments of its performance in serving the people in an era of sophisticated technology and returning political parties as political parties with modern and actual ideas. In that sense, the understanding of this paper captures that PSI as a political party wants to be a representation of urban and educated people, especially the young generation who care about Indonesia's future (Sumardy, interview, 2020).

\section{Selection of the target audience}

Meanwhile, the leading cause of PSI's victory abroad, based on the statements of interviewees, was that PSI, a new political party offering novelty and modern political thought, had more support from people abroad who understood modern political ideas abroad. A country, a political orientation offering actuality and novelty in thinking to distribute people's welfare was an essential element that made PSI closer to these ideas to get more significant support in big cities (Sumardy, interview, 2020). It did not just happen overseas. In big cities in Indonesia such as Jakarta, Surabaya and Semarang, PSI also received significant votes. As in Surabaya, it became a strong contender for PDI-P as the dominant national party. This tendency for PSI to get high votes did not occur in all regions; it only occurred in big cities with high consumption of voter information, especially from social media where the national PSI was relatively higher in volume than other Jokow-Ma'ruf supporting parties (Surabaya Bisnis, 2019).

Meanwhile, the medium used to support political campaign programs was prioritized on social media platforms to convey messages widely. Inevitably, every message articulated consistently emphasized the issues of corruption and intolerance.

"We only utilize social media as the medium to deliver our campaign messages with consistency in our theme of corruption and intolerance in Indonesia; this is our main strategy to do our political communication" (Sumardy, interview, 2020).

The choice of the platform is in line with PSI's target audience, young people. Social media had a significant influence on the political choices of young people. A survey of the Indonesian Institute of Sciences (LIPI) revealed that $60.6 \%$ of generation $\mathrm{Z}$ or young people born in 1995-2005 accessed news regarding politics through social media. In detail, LIPI divided $60.6 \%$ of first-time voters who accessed political news via the internet into three intensity categories. As many as 36\% accessed political news via the internet, but rarely. As many as $22.3 \%$ often accessed political news through social media, the remaining $2.3 \%$ were very often (Kata Data, 2018). 
PSI political campaign has been considered fresh and novel to attract attention. At the initial level, it was an important asset. However, it had not been able to read the broader interests of the voters. As a result, the PSI voter segment was relatively narrow, but this party had not been able to turn the interest of some voters into a political choice in polling stations. However, if PSI is consistent and able to emphasize differences in identity and product offerings such as policy alternatives and various other essential issues, the voter niche may grow, especially among increasingly critical urban youth (Susanto, interview, 2020). In that sense, PSI's political campaign strategy targeting educated people, especially urban youth, must be carried out consistently so that its voters' niche can continue to expand as the modality to gain bigger votes in the 2024 general election.

\section{CONCLUSION}

This paper concluded that PSI had conducted communication planning and communication management in its political campaign by emphasizing data usage collected from the internal party. These data strengthened the political campaign program of PSI, focusing on two parametric issues: corruption and intolerance. From there, PSI's communication strategy rested on the vision and mission of the party, aiming to restore the role of political parties in Indonesia as a pillar of democracy that could work to voice the political aspirations of the people and solve problems faced by the community. Based on this vision and mission, PSI determined programs and activities to fight corruption and intolerance in Indonesia. These programs were well received by more open-minded New Zealand voters as the majority consisted of the younger generation of Indonesians studying or working there. The political campaign program carried out is in line with the goals and results set by PSI; philosophically, PSI wants to appear as a party close to the people, be consistent in getting people's assessments regarding its performance in serving the people in an era of sophisticated technology, and return the idea of the political party with modern and relevant ideas. In that sense, the understanding of this paper captures that PSI as a political party wants to be a representation of urban and educated people, especially the young generation who care about Indonesia's future.

\section{ACKNOWLEDGEMENT}

This research was possible made and supported by the grant from National Research and Innovation Agency of Indonesia (DIKTI). We thank Mr. Sumardy, Chief of National Leadership of PSI for providing us valuable data on the communication strategy during the political campaign 2019, Ms. Ellen Tambunan, The Indonesian consulate in New Zealand, for deliberating the overview on the implementation of General Election in New Zealand, as well to Mr.Raka as the representative of the voter in New Zealand, Mr. Arif Susanto as our expert for the analysis on the overall political prepective toward the communication strategy of PSI during the General Election 2019, Mr. Arif Darmawan from Soedirman University for his unwevary support. We also would like to thank The Institute Communication and Business LSPR for their endless support. Last and most importantly we like to express our gratitude to our family and friends who have always been there for us.

\section{ENDNOTE}

\begin{abstract}
As explained by Robert A. Dahl, Demokrasi dan Para Pengkritiknya, Jakarta: Yayasan Obor Indonesia, 1992,, hlm. 33. Also see Syamsudin Haris, "Struktur,Proses, dan Fungsi Pemilihan Umum: Catatatan Pendahuluan, dalam Syamsudin Haris (ed), Menggugat Pemilihan Umum Orde Baru,Jakarta : Yayasan Obor Indonesia dan PPW-LIPI, 1998, page. 7.
\end{abstract}

\section{REFERENCE}

Afifiyah, S. (2019, May 25). Daftar Partai Politik Pemenang Pemilu 2019 | Tagar ID. Retrieved from https://www.tagar.id/daftar -partai-politik-pemenang-pemilu-2019

Ardaneswari, I. (2020, July 5). Sejarah Pemilu 2004: Pertama Kali Rakyat Memilih Langsung Presiden - Tirto.ID. Retrieved from https://tirto.id/sejarah-pemilu-2004-pertama-kali-rakyat -memilih-langsung-presiden-dme7

Berebut 730 Ribu Suara TKI Ramai-ramai Parpol Buka Perwakilan d Luar Negeri. (2009, February 2). Surya.co.id. Retrieved from https://surabaya.tribunnews.com/2009/02/02/berebut-730 -ribu-suara-tki-ramai-ramai-parpol-buka-perwakilan-di-luar -negeri

Bernays, E.L. (1952). Public Relations. Norman: University of Oklahama Press.

Budiarjo, M. (1982). Partisipasi dan Partai Politik (Sebuah Bunga 
Rampai). Jakarta: PT. Gramedia.

Budiarjo, M. (2002). Dasar-Dasar Ilmu Politik. Jakarta: Gramedia Pustaka Utama.

Cangara, H. (2011). Pengantar Ilmu Komunikasi. Jakarta: PT Raja Grafindo. Persada.

Cangara, H.(2012). Pengantar IImu Komunikasi. Jakarta: PT Raja Grafindo Persada.

Carroll, C., McCombs, M. (2003). Agenda-setting Effects of Business News on the Public's Images and Opinions about Major Corporations. Corp Reputation Rev 6, 36-46. DOI: https://doi.org/10.1057/palgrave.crr.1540188

CNN Indonesia. (2019). KPU Sebut Pemungutan Suara di Luar Negeri Dimulai Hari Ini. Retrieved from CNN Indonesia: https://www.cnnindonesia.com/nasional/20190408153731 -32-384297/kpu-sebut-pemungutan-suara-di-luar-negeri -dimulai-hari-ini

Creswell, J. W., \& Creswell, D. (2017). Research design: Qualitative, quantitative, and mixed methods approaches. ( $5^{\text {th }}$ ed.). Newburry, California: Sage Publications.

Cutlip, Scott.M, et all, (2000). Effective Public Relations. New Jersey: Prentice Hall.

Effendy, O.U. (2003). Ilmu, Teori dan Filsafat Komunikasi. Bandung : Citra Aditya Bakti

Fajar. (2019, March 18). Karangan Bunga Duka Cita dari PSI di Kedubes New Zealand. Detik.com. Retrieved November 1, 2020, from https://news.detik.com/berita/d-4473482/ karangan-bunga-duka-cita-dari-psi-di-kedubes-new-zealand

Hukum Online. (2020). Sistem Proporsional Terbuka dan Kelemahannya dalam Pemilu ... Halaman 2 - hukumonline .com. Hukum Online. https://www.hukumonline.com/berita /baca/lt5eddef5e9ac7a/sistem-proporsional-terbuka-dan -kelemahannya-dalam-pemilu? page $=2$

Huntington, S.P. (1991). The Third Wave: Democratization in the Late 20th Century. Oklahama: University of Oklahoma Press.

KPU Sebut Pemungutan Suara di Luar Negeri Dimulai Hari Ini (nd). CNN Indonesia. Retrieved from https://www.cnnindonesia. com/nasional/20190408153731-32-384297/kpu-sebutpemungutan-suara-di-luar-negeri-dimulai-hari-ini

Kata Data. (2018). LIPI: 60\% Anak Muda Akses Berita Politik Lewat Media Sosial - Katadata.co.id. Retrieved from https:// katadata.co.id/pingitaria/digital/5e9a55e40ff3a/lipi-60-anak -muda-akses-berita-politik-lewat-media-sosial

Kemenkumham. (2020). Peran Partai Politik dalam Penyelenggaraan Pemilu yang Aspiratif dan Demokratis. Dirjen PP Kemenkumham. Retrieved from http://ditjenpp. kemenkumham.go.id/htn-dan-puu/507-peran-partai-politik -dalam-penyelenggaraan-pemilu-yang-aspiratif-dan -demokratis.html

Kementerian Luar Negeri. (2019). Jokowi dan PSI unggul di Selandia Baru. Retrieved from https://kemlu.go.id/wellington /id/news/189/jokowi-dan-psi-unggul-di-selandia-baru

Kompas. (2019, May 21). Tak Lolos ke DPR, PSI Jadikan Pemilu 2019 Modal untuk Pemilu Berikutnya. Kompas.com. Retrieved from https://nasional.kompas.com/read/2019 /05/21/12144241/tak-lolos-ke-dpr-psi-jadikan-pemilu-2019 -modal-untuk-pemilu-berikutnya

Liliweri, A. (2010). Strategi Komunikasi Masyarakat. Yogyakarta: LKIS Pelangi Aksara.

Mata Mata Politik. (2019). Pemilihan Legislatif 2019: Parpol
Pemenang dan Pecundang. Matamatapolitik.com. Retrieved on November 2019 from https://www.matamatapolitik.com /analisis-parpol-pemenang-dan-pecundang-di-pemilihan -legislatif-indonesia-2019/

Nimmo, D. (1989). Komunikasi Politik: Khalayak dan Efek. Bandung: Remadja Karya W.

Panca Rini, R.A. (2019, April 18). Hasil Real Count 2 TPS di Selandia Baru, Jokowi Menang Telak, PSI Raih Suara Tertinggi Pemilu 2019. Tribbun Wow. Retrieved from https://wow.tribunnews.com/2019/04/18/hasil-real-count -2-tps-di-selandia-baru-jokowi-menang-telak-psi-raih-suara -tertinggi-pemilu-2019

Partai Solidaritas Indonesia (2018). Mengenal PSI, Partai Milenial Peserta Baru di Pemilu 2019 PSI.Id. Retrieved from https://psi.id/berita/2018/02/20/mengenal-psi-partai-milenial -peserta-baru-di-pemilu-2019/

Partai Solidaritas Indonesia. (2019). Apa itu PSI?. psi.id. Retrieved November 1, 2020, from https://psi.id/berita/content/apa -itu-psi/

Partai Solidaritas Indonesia. (2019). Gandeng ICW, PSI Bekali Anggota Legislatif Terpilih Agar Tidak Korupsi. psi.id. Retrieved June 26, 2019 from https://psi.id/berita/2019/06 /26/gandeng-icw-psi-bekali-anggota-legislatif-terpilih-agar -tidak-korupsi/

PDIP Alami Himpitan Elektoral dengan PSI di Surabaya (2019, May 17). Bisnis ID. Retrieved from https://surabaya.bisnis.com /read/20190517/531/923887/pdip-alami-himpitan-elektoral -dengan-psi-di-surabaya

Permana, R. (2019). Awal Presiden Dipilih Rakyat: Dicetuskan di Era Gus Dur, Diteken Mega. Detik News. Retrieved on November 2019 from https://news.detik.com/berita /d-4802023/awal-presiden-dipilih-rakyat-dicetuskan-di-era -gus-dur-diteken-mega

Sumardy. (2020). Interview of "Strategi Komunikasi Partai Solidaritas Indonesia" on zoom media. 40 minutes.

Susanto. (2020). Interview of "Strategi Komunikasi Partai Solidaritas Indonesia" on zoom media. 40 minutes.

Swanson, D.L \& Mancini, P. (1996). Politics, Media, and Modern Democracy: An International Study of Innovations in Electoral Campaigning and Their Consequences. New York: Greenwood Publishing Group.

Undang-Undang Nomor 10 tahun 2008 tentang Pemilihan Umum Anggota DPR,DPD, dan DPRD. (2008, March 31). HukumOnline.Com. Retrieved on November 2020 from https://www.hukumonline.com/pusatdata/detail/28062/ undangundang-nomor-10-tahun-2008/document

Raharja. (2020). Interview of "Strategi Komunikasi Partai Solidaritas Indonesia" on zoom media. 40 minutes. 